\title{
MBD3 wt Allele
}

National Cancer Institute

\section{Source}

National Cancer Institute. MBD3 wt Allele. NCI Thesaurus. Code C94735.

Human MBD3 wild-type allele is located in the vicinity of 19p13.3 and is approximately 16 $\mathrm{kb}$ in length. This allele, which encodes methyl-CpG-binding domain protein 3, plays a role in the modulation of histone modification, transcription and DNA methylation. 